\title{
Are mothers always right? When acute meningitis is something more
}

\author{
Catarina Gomes, ${ }^{1}$ Patrícia Romão, ${ }^{1}$ Jose Miguens, ${ }^{2}$ Ana Mouzinho ${ }^{1}$
}

'Department of Pediatrics, Hospital de Santa Maria Centro Hospitalar Lisboa Norte, Lisboa, Portugal

${ }^{2}$ Department of Neurosurgery, Centro Hospitalar Lisboa Norte-Hospital Santa Maria, Lisbon, Portugal

\section{Correspondence to}

Dr Catarina Gomes, catarina.j.gomes@gmail.com

Accepted 2 October 2015

\section{SUMMARY}

A 22-month-old girl with a history of a congenital occipital cutaneous cyst was brought to the paediatric emergency department for lethargy and occipital headache. She had been discharged 5 days before for acute meningitis without bacterial isolates. At physical observation, she presented with irritability and neck hyperextension, with negative meningeal signs. CT scan revealed a vermian cyst and hydrocephalus. She was submitted to neurosurgery with removal of an infected midline dermoid cyst with a fistulous track to the skin. Surgery was successful and without complications. During follow-up, the child was asymptomatic with normal psychomotor development.

\section{BACKGROUND}

The incidence of acute bacterial meningitis has decreased in the last decades, but it is still far from being a rare condition. Although variable according to region, it is estimated that the median incidence in children under 5 years of age is 34 per 100000 child-years globally, and 20.8 per 100000 childyears in Europe. ${ }^{1}$ Lumbar puncture (LP) is the cornerstone of diagnosis, however, children with elevated intracranial pressure are at risk of cerebral herniation. We present the case of a child with acute meningitis diagnosed after LP, who was later found to have an intracranial dermoid cyst with hydrocephalus.

\section{CASE PRESENTATION}

A 22-month-old girl presented with lethargy and occipital headache.

She had a personal history of a congenital occipital cutaneous cyst, with no intracranial communication detected in the ultrasound.

Eight days earlier, she had been brought to our paediatric emergency department (PED), with lowgrade fever and vomiting. At observation, she was prostrate and presented neck stiffness. From the blood panel, we highlighted leucocytosis with neutrophilia and elevated $\mathrm{C}$ reactive protein (table 1). LP revealed clear cerebrospinal fluid (CSF) with elevated white cell count, normal protein levels and a decreased CSF-serum glucose ratio (table 1). She was diagnosed with acute meningitis with no bacterial isolates (negative blood and CSF cultures). During admission, her mother pointed out a possible association with the congenital occipital cutaneous cyst; she had, with a previous ultrasound, been reassured that it was not a concern. However, she had always felt that the head cyst, despite the previous investigation, had the potential for complications. The child improved rapidly during the first $48 \mathrm{~h}$ of ceftriaxone, with no fever and no vomiting. Antibiotic therapy with ceftriaxone was maintained for 7 days, based on clinical parameters.

After discharge, the baby developed progressive lethargy and occipital headache, without fever or vomiting, and returned to the PED $36 \mathrm{~h}$ after the

Table 1 Laboratory test results

\begin{tabular}{|c|c|c|c|c|}
\hline & Unit & First admission & $\begin{array}{l}48 \mathrm{H} \\
\text { ceftriaxone }\end{array}$ & $\begin{array}{l}\text { Second } \\
\text { admission }\end{array}$ \\
\hline \multicolumn{5}{|l|}{ Blood tests } \\
\hline Leucocytes & $\times 10^{9} / \mathrm{L}$ & 17.41 & 5.54 & 3.52 \\
\hline Neutrophils & $\%$ & 80.9 & 59.5 & 44.5 \\
\hline $\mathrm{C}$ reactive protein & $\mathrm{mg} / \mathrm{L}$ & 49 & 22 & 1 \\
\hline Glucose & $\mathrm{mmol} / \mathrm{L}$ & 5.83 & & \\
\hline \multicolumn{5}{|l|}{ CSF tests } \\
\hline Colour & & Clear & & \\
\hline White cell count & $/ \mu \mathrm{L}$ & $\begin{array}{l}1400 \text { with predominance of } \\
\text { polymorphonuclear cells }\end{array}$ & & \\
\hline Proteins & $\mathrm{mg} / \mathrm{L}$ & 495 & & \\
\hline Glucose & $\mathrm{mmol} / \mathrm{L}$ & 1.72 & & \\
\hline CSF-serum glucose ratio & & 0.3 & & \\
\hline \multicolumn{5}{|l|}{ Cultures } \\
\hline Blood & & Negative & & \\
\hline CSF & & Negative & & \\
\hline $\begin{array}{l}\text { Cyst pus (Gram stain, aerobic and } \\
\text { anaerobic cultures) }\end{array}$ & & & & Negative \\
\hline
\end{tabular}

To cite: Gomes C, Romão P, Miguens J, et al. BMJ Case Rep Published online: [please include Day Month Year] doi:10.1136/ bcr-2015-211658
CrossMark 


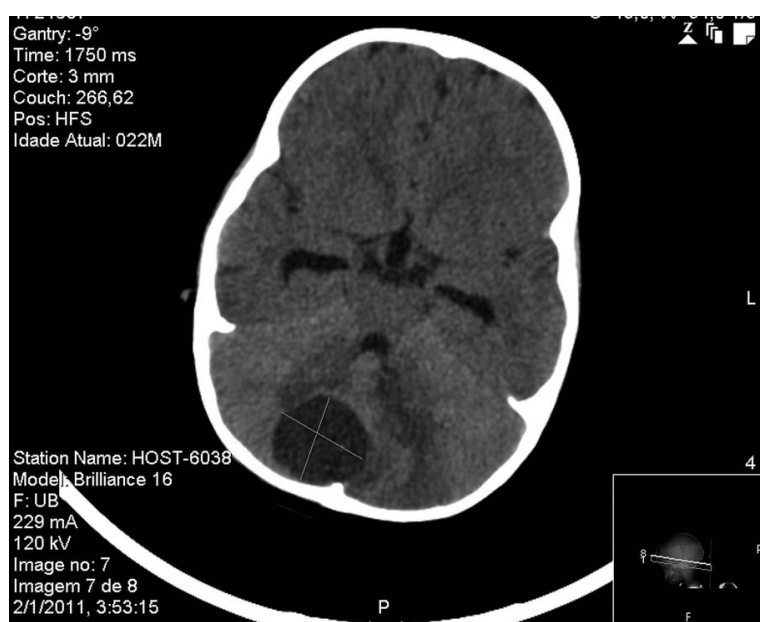

Figure 1 Head CT scan: vermian cyst with surrounding oedema and distortion of the fourth ventricle.

last ceftriaxone administration. Her mother once more insisted that the child's headache was associated with the occipital cyst region. At physical observation, irritability and a preferential position with neck hyperextension were noted, with negative Kernig and Brudzinsky signs and no fever or vomiting.

Blood tests had negative infection parameters (table 1) and the CT/MRI of the head revealed a vermian cyst with supratentorial hydrocephalus (figures 1-3).

Our patient underwent occipital craniotomy with total removal of a midline infected dermoid cyst, fistulous cutaneous track and occipital extracranial dermoid cyst. The histopathological examination of the cyst wall was consistent with a dermoid cyst, containing both epidermal and dermal elements. The postoperative course was uneventful and the baby was discharged after 2 weeks of empiric antibiotic therapy (metronidazole, cefotaxime and vancomycin), with resolution of the obstructive hydrocephaly. The bacterial culture of the cyst content was negative.

\section{OUTCOME AND FOLLOW-UP}

During 4-year follow-up, there were no relapses and the child maintained adequate psychomotor development.

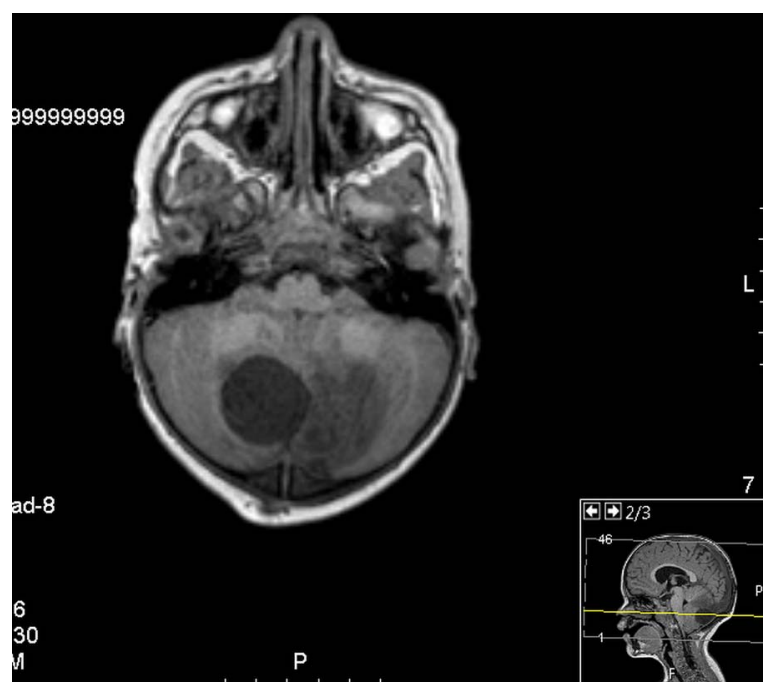

Figure 2 Head MRI (axial view): expansive lesion in the cerebellar vermis, with mass effect.

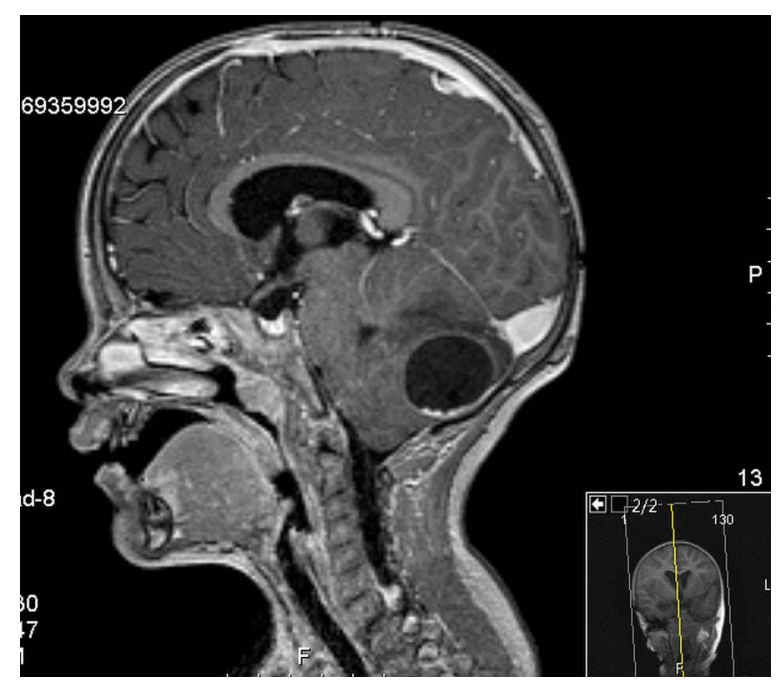

Figure 3 Head MRI (sagittal view): expansive lesion in the cerebellar vermis, with apparent fistulous track to the skin.

\section{DISCUSSION}

Intracranial dermoid cysts are rare, accounting for $<1 \%$ of all central nervous system tumours. They are formed by the inclusion of epithelial cells during neural tube closure in fetal development. These cysts contain a thick fluid formed by lipids, hair follicles and decomposed epithelial cells, surrounded by a fibrous capsule. ${ }^{2}{ }^{3}$ Dermoids are typically located at the midline posterior fossa, vermis and spine. ${ }^{4}$ They can be associated with hydrocephalus, seizures or infectious complications, such as recurrent meningitis or intracranial abscess, often associated with a cutaneous sinus tract. $^{5-8}$ Antibiotic therapy in these cases should cover Staphylococcus aureus, as this is the most common offending pathogen. ${ }^{9}$ After diagnosis, the treatment is surgery with total excision, which, in symptomatic patients, should be performed as soon as possible since it is effective in preventing complications. ${ }^{67}$

In the presence of a midline congenital cyst and suspicion of meningitis, a CT of the head should be performed to exclude an intracranial dermoid cyst before LP. In such cases, performing an LP can be catastrophic, resulting in significant morbidity or death. An image scan was not carried out in this case as the occipital cutaneous cyst had already been investigated by ultrasound, and no intracranial communication was found. Moreover, except for meningeal signs, the neurological examination was normal. Retrospectively, we believe that, in the presence of an occipital cyst, the previous CT/MRI of the head should have prompted the LP decision.

This case demonstrates the need for a high level of suspicion in the presence of a child with a known midline abnormality, recurrent meningitis or intracranial abscess.

\section{Learning points}

- In the presence of a suspected or known midline abnormality, consider imaging before performing a lumbar puncture.

- Despite being rare, an intracranial dermoid cyst is an entity to remember and can be associated with recurrent meningitis or intracranial abscess.

- In the presence of a midline cyst consider the possibility of Staphylococcus aureus meningitis and add vancomycin.

- Listen to the parents-they are the experts of their child. 
Acknowledgements The authors would like to acknowledge Dr Ana Zagalo. Competing interests None declared.

\section{Patient consent Obtained.}

Provenance and peer review Not commissioned; externally peer reviewed.

\section{REFERENCES}

1 Lukšič I, Mulić R, Falconer R, et al. Estimating global and regional morbidity from acute bacterial meningitis in children: assessment of the evidence. Croat Med J 2013;54:510-18.

2 Vinchon M, Lejeune JP, Krivosic I, et al. Cranio-cerebral dermoid and epidermoid cysts. Classification and pathogenesis. Neurochirurgie 1995;41:29-37.

3 Gelabert-González M. Intracranial epidermoid and dermoid cysts. Rev Neurol 1998;27:777-82.
4 Cobbs CS, Pitts $L H$, Wilson CB. Epidermoid and dermoid cyst of the posterior fossa. Clin Neurosurg 1997;44:511-28.

5 Mann GS, Gupta A, Cochrane DD, et al. Occipital dermoid cyst associated with dermal sinus and cerebellar abscesses. Can J Neurol Sci 2009;36:487-90.

6 Naderi $\mathrm{S}$, Nejat $\mathrm{F}$, Shahjouei $\mathrm{S}$, et al. Cranial dermal sinus: presentation, complications and management. Pediatr Neurosurg 2012;48:86-92.

7 Cherian A, Baheti NN, Easwar HV, et al. Recurrent meningitis due to epidermoid. J Pediatr Neurosci 2012;7:47-8.

8 Orakcioglu $B$, Halatsch ME, Fortunati $M$, et al. Intracranial dermoid cysts: variations of radiological and clinical features. Acta Neurochir (Wien) 2008;150:1227-34.

9 Mohindra S, Gupta R, Chhabra R, et al. Infected intraparenchymal dermoids: an underestimated entity. I Child Neurol 2008; 23:1011-16

Copyright 2015 BMJ Publishing Group. All rights reserved. For permission to reuse any of this content visit http://group.bmj.com/group/rights-licensing/permissions.

BMJ Case Report Fellows may re-use this article for personal use and teaching without any further permission.

Become a Fellow of BMJ Case Reports today and you can:

- Submit as many cases as you like

- Enjoy fast sympathetic peer review and rapid publication of accepted articles

- Access all the published articles

- Re-use any of the published material for personal use and teaching without further permission

For information on Institutional Fellowships contact consortiasales@bmjgroup.com

Visit casereports.bmj.com for more articles like this and to become a Fellow 